\title{
Atrazine Residues in Surface Water from Various Agricultural Areas of El- Behera Governorate, Egypt
}

\author{
Mohamed A.F. Abuzeid ; Atef M.K. Nassar ; Alaa M. H. Khozimy ${ }^{1}$
}

\begin{abstract}
Herbicides contribute significantly to increasing and enhancing both crop yield and quality through compacting herbs that compete with these crops. However, overuse of these chemicals might adversely affect aquatic ecosystem microorganisms and eventually human health. Residues of the extensively applied herbicide atrazine in irrigation surface water samples from El-Behera, the leading agricultural Governorate in Egypt. Water samples were collected from 26 sites in El-Behera and analyzed using gas chromatography coupled with a mass spectrometry detector (GC-MS). Results revealed significant variation of atrazine levels in irrigation water between these 26 sites. Water samples from Kafr El-Dawwar had the least amount $(3.125 \pm 0.0894 \mu \mathrm{g} / \mathrm{L})$, while samples from Hosh Essa had the greatest residue of atrazine $(109.181 \pm 15.778$ $\mu \mathrm{g} / \mathrm{L})$. The obtained results may represent the trends and amounts of atrazine used in the El-Behera Governorate. These results may be concerning to the potential adverse effects due to the inappropriate use of atrazine.
\end{abstract}

Keywords: Atrazine; Herbicides; Surface water; Aquatic ecosystem; GC-MS; Residues Introduction

\section{INTRODUCTION}

Weed competes with plants on acquiring water, nutrients, and light, causing a significant reduction in yield quantity and/or quality (El-Sobky \& El-Naggar, 2016). For example, a reduction in corn yield might reach 30 to $90 \%$ if not controlled (Ali et al., 2003; Mahmoodi \& Ali, 2009; Abouzinea et al., 2013; Pannacci \& Onofri, 2016). Therefore, farmers utilize weed control practices (Khaliq et al., 2004). Among weed management strategies is the application of pesticides (Williamson et al., 2008; Radwan and Nassar, 2011). The amount of pesticides used in Egypt was about 12178 tonnes in 2019, and about 2040 tonnes of herbicides were applied to control various weeds in different crops (FAOSTAT, 2021).

In particular, the most widely used in weed control of corn crops (Maceljski et al., 2005). After spraying on crops, it can enter water resources because of its high mobility through soil (Waring and Moore, 2004). Its residues were identified in surface, ground, and drinking water samples (Gojmerac et al., 1996). Hussein et al., (1996) reported that atrazine might reach aquatic environments from spray drifts, careless application, or indirectly from irrigation by wastewater. Upon reaching the water environment, atrazine or triazine-based herbicides are not easily degraded by microbial or hydrolytic processes (Gamble et al., 1983). However, WHO reports (1996) pointed out that atrazine can be degraded in surface water by photolysis and microorganisms and that the half-life is 20 - 50 days at $20-25^{\circ} \mathrm{C}$ under laboratory conditions (USEPA, 1988). It has been detected in surface water at concentrations exceeding $0.1 \mathrm{~g} / \mathrm{l}$ (Solomon et al., 1996; Environment Agency, 1997).

Atrazine residues in water may pose health risks to the reproductive system (Cooper et al., 2000; Gojmerac et al., 2004). Also, it is considered an endocrine disruptor (Moore \& Waring, 1998) and a probable human carcinogen (Luciane et al., 2010). Moreover, atrazine significantly affected sperm numbers significantly, premature birth, miscarriage, and various congenital disabilities in humans (Ackerman, 2007; Pathak \& Dikshit, 2011). Although atrazine was banned in the European Union in 2003 (Bethsass and Colangelo, 2006), it is still being used illegally as a major herbicide in Egypt.

The potential of contaminating water resources and soil with atrazine may cause pollution to the environment and bring harmful effects to humans and other animals. It might be concentrated in plants and transferred to the food chain (Topp et al., 2000). Therefore, the objective of the current study was to assess atrazine residues in surface water of agricultural irrigation streams in El-Behera Governorate, a central agricultural province in Egypt.

\section{MATERIALS AND METHODS}

\section{Chemicals}

Atrazine (2-chloro-4-ethylamino-6-isopropylamino1,3,5-triazine); reference standard $>99 \%$ purity was purchased from Cornell Lab, Cairo, Egypt. Triphenyl phosphate (TPP), Acetonitrile ( $\mathrm{MeCN})$, acetone, glacial acetic acid, and dispersive solid-phase extraction and cleanup kits (Agilent Technologies catalog \# 5982-0650 and 5982-5056, respectively) were purchased from Arabian Group for Integrated Technologies

DOI: 10.21608/asejaiqjsae.2022.219626

${ }^{1}$ Department of Plant Protection, Faculty of Agriculture, Damanhur

University, Damanhur, P.O. Box 59 El-Behera, Egypt.

Corresponding Author: mohamed.abuzeid@agr.dmu.edu.eg

Received January 10, 2022, Accepted, February 13, 2022. 
(AGITECH), Cairo, Egypt. Sodium sulfate anhydrous $\left(\mathrm{Na}_{2} \mathrm{SO}_{4}\right)$ was purchased from BDH Laboratory Supplies, BH 151T, England. Primary secondary amine (PSA, $40 \mu \mathrm{m}$ sorbent- Bonesil) was obtained from Agilent Technologies, Arabian Group for Integrated Technologies (AGITECH), Cairo, Egypt. All other reagents used were of high quality. Standard curve of atrazine was carried out using serial concentrations of atrazine $(0.1$ and $50 \mu \mathrm{g} / \mathrm{L})$ which prepared in acetonitrile.<smiles>CCNc1nc(Cl)nc(NC(C)C)n1</smiles>

Atrazine

\section{Water samples locations}

Surface water samples of agricultural irrigation streams $(n=78)$ were collected from 26 sampling sites at El-Behera Governorate. The sampling regions (covering almost all the Governorate) were El- Mahmoudia, Zarkone, Kom El-Nasr, Ficha, Kafr Tekla, Edfina, Zawiat Ghazal, Abou Hommos, Barket Ghatas, ElKazaz, Kafr El-Dawwar, Abyss, Damanhur, Itay El Barud, Denchal, Kom Hamada, Monchat Nassar, Shubrakhit, Abu Menjouj, Elmasry village, Hosh Issa, El-Nubaria, Abu El Matamir (Mariout and Sidnawy), and Genaklis (Map 1).

Samples were collected in summer 2018 according to the method described by Myers (2006). Water samples were taken at a $50 \mathrm{~cm}$ depth from the water surface, kept in screw cap 3 L capacity dark glass bottles, and immediately transported to the laboratory for analysis. The water samples were filtrated through a cotton funnel to remove debris. The filtrated water samples were extracted for atrazine residue analysis.

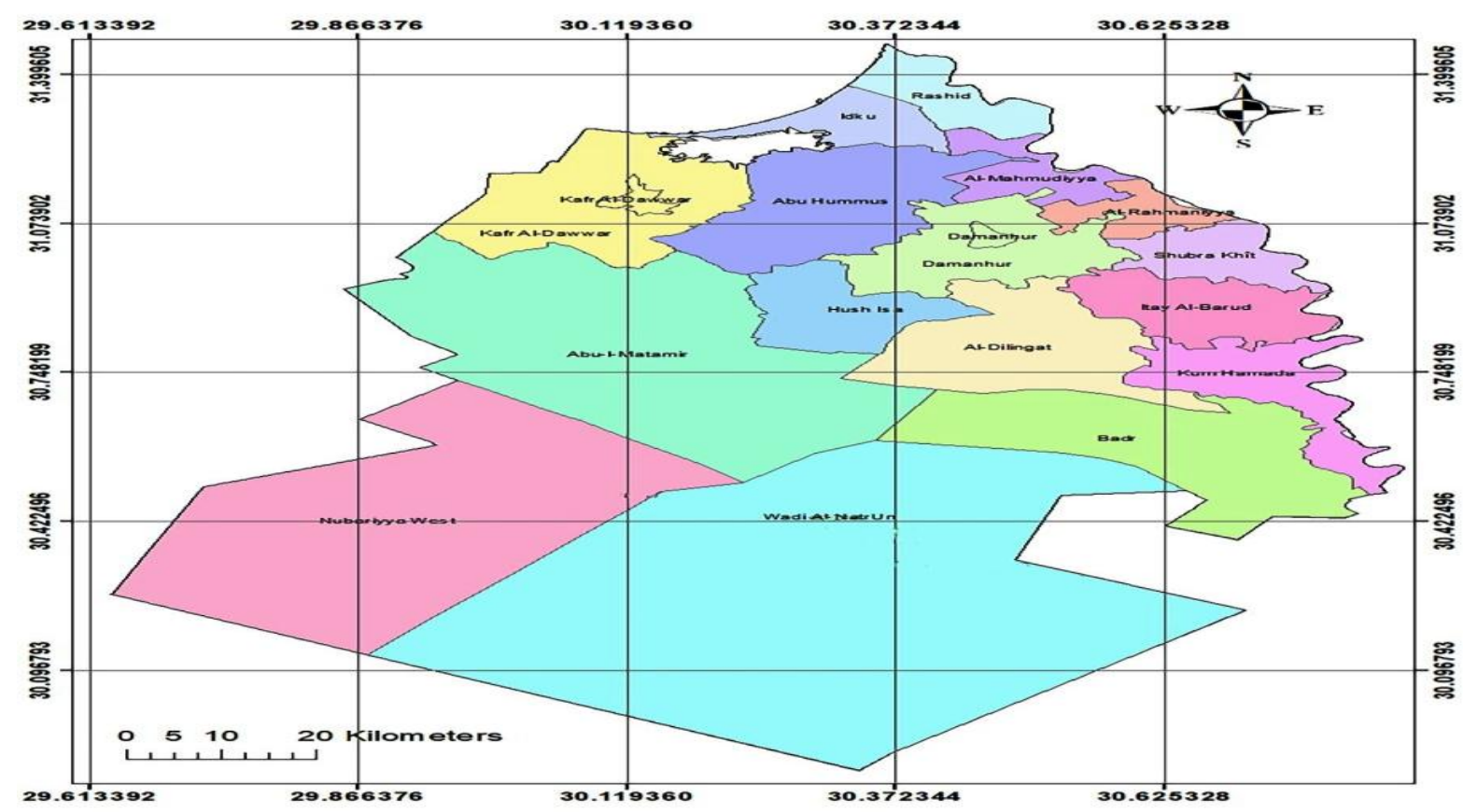

Map 1. Sampling locations from agricultural areas across El-Behera Governorate 


\section{Extraction and measurement of atrazine residues}

The extraction and cleanup of atrazine residues were carried out using the dispersive solid-phase extraction and cleanup kits according to the method of QuEChERS with a slight modification of Anastassiades et al. (2003). In $50 \mathrm{ml}$ Falcon tubes, $10 \mathrm{ml}$ of water samples were extracted with $10 \mathrm{ml}$ of 0.1 percent acidified acetonitrile. After vigorously agitating the tubes for one minute with a Vortex mixer, $4 \mathrm{~g}$ of anhydrous $\mathrm{MgSO} 4$ and $1 \mathrm{~g} \mathrm{NaCl}$ were added to each tube and thoroughly mixed for one minute. After mixing $50 \mathrm{~L}$ of Triphenyl phosphate (TPP) (internal standard) solution for 30 seconds, extracts were centrifuged for 10 minutes at 4000 rpm (Hermle Labortechnik GmbH, Siemensstr, D78564 Wehingen, Germany). Following that, $1 \mathrm{ml}$ of the upper $\mathrm{MeCN}$ layer was transferred into $15 \mathrm{~mL}$ Falcon tubes containing $25 \mathrm{mg}$ PSA sorbent and $150 \mathrm{mg}$ anhydrous $\mathrm{MgSO}_{4}$ and inversely shaken. Samples were centrifuged for $5 \mathrm{~min}$ at $4000 \mathrm{rpm}$. Samples were extracted and cleaned up in triplicates. About $0.5 \mathrm{~mL}$ of extracts were transferred into amber HPLC vials for GC/MS analysis.

\section{GC/MS running conditions}

In order to analyze the samples, an Agilent Technologies gas chromatography system model 7890B coupled with a mass spectrometry model 5977A (GC/MS) instrument and an autosampler (Agilent, Little Falls, DE) was used. The GC had a split/splitless injection inlet as well as electronic pressure control (EPC). MSD Chem Station software (Ver. F.01.03.2357) was used to control the system, and Mass Hunter GC/MS acquisition software was used to analyze the data (Ver. B.07.03.2139). In splitless mode, extracts and recovery samples (2 1) were injected into the GC/MS system. To detect atrazine residues, an HP5MS capillary column $(30 \mathrm{~m} \mathrm{X} 0.53 \mathrm{~mm}$ i.d. $0.25 \mathrm{~m}$ film thickness) was used. At a constant flow rate of 1.1 $\mathrm{ml} / \mathrm{min}$, helium was used as the carrier gas. According to AOAC (2007), Separation conditions were completed with an initial column temperature set at $80^{\circ} \mathrm{C}$ for 6 min. It was increased to $215^{\circ} \mathrm{C}$ at $15^{\circ} \mathrm{C} / \mathrm{min}$ (hold for 1 $\min$ ), then to $230^{\circ} \mathrm{C}$ at $5^{\circ} \mathrm{C} / \mathrm{min}$ and finally to $290^{\circ} \mathrm{C}$ at $5^{\circ} \mathrm{C} / \mathrm{min}$ (hold for $2 \mathrm{~min}$ ). Atrazine residues were identified by their full mass spectra scans and retention time using the total ion current compared to that of the standard material of atrazine.

\section{Calibration curve and recovery}

The quality criteria were monitored according to the requirements of the Codex Alimentarius Committee. The Calibration curve was constructed using 1, 10, 20, 50 , and $100 \mu \mathrm{g} / \mathrm{L}$. The regression equation of the standard curve was used to calculate the amounts of detected herbicide. Recovery and reproducibility were evaluated by spiking blank water samples with 5 and 10 $\mu \mathrm{g} / \mathrm{L}$ and each concentration was repeated three times. From the standard curve, it can determine the limits of detection (LOD) and quntification (LOQ).

The precision of the analytical method was confirmed through the repeatability (intra-day assay) and intermediate precision (inter-day assay) (ICH, 2005). The intra-day and inter-day precision of the method was determined by repeating the analysis of recovery samples on the same day and over five consecutive days, respectively. All fortified samples were extracted as mentioned above. The precision was expressed as coefficient of variation percentages ((mean/standard deviation) $\times 100$ ). The limits of quantification (LOQs) were calculated from the signal-to-noise $(\mathrm{S} / \mathrm{N})$ ratios of the samples with the lowest concentration level of atrazine.

\section{Statisticl Analysis}

Data were statistically analyzed as completely randomized design with locations as main factor using the procedure general linear model (PROC GLM) of the Statistical Analysis System (SAS) version 9.3.

\section{RESULTS AND DISCUSSION}

The calibration curve of the atrazine standard is shown in Figure 1. Quality parameters of the employed method showed that recovery percentages of atrazine were 94.7 and $96.3 \%$ at 5 and $10 \mu \mathrm{g} / \mathrm{L}$, respectively (Table 1). Also, the coefficients of variation (CV \%) expressed in intra- and inter-assay values were 1.433 and 2.049 and 4.912 and $5.406 \%$ for 5 and $10 \mu \mathrm{g} / \mathrm{L}$, respectively. Method limits of detection (LOD) and quantification (LOQ) of atrazine were 2.343 and 7.100 $\mu \mathrm{g} / \mathrm{L}$, respectively, which were in agreement with the results of Bonansea et al., (2013). Moreover, the $\mathrm{R}^{2}$ value was $98.86 \%$. The previous results verified that the employed method was acceptable for the analysis of atrazine residues according to $\mathrm{ICH}$ requirements. 


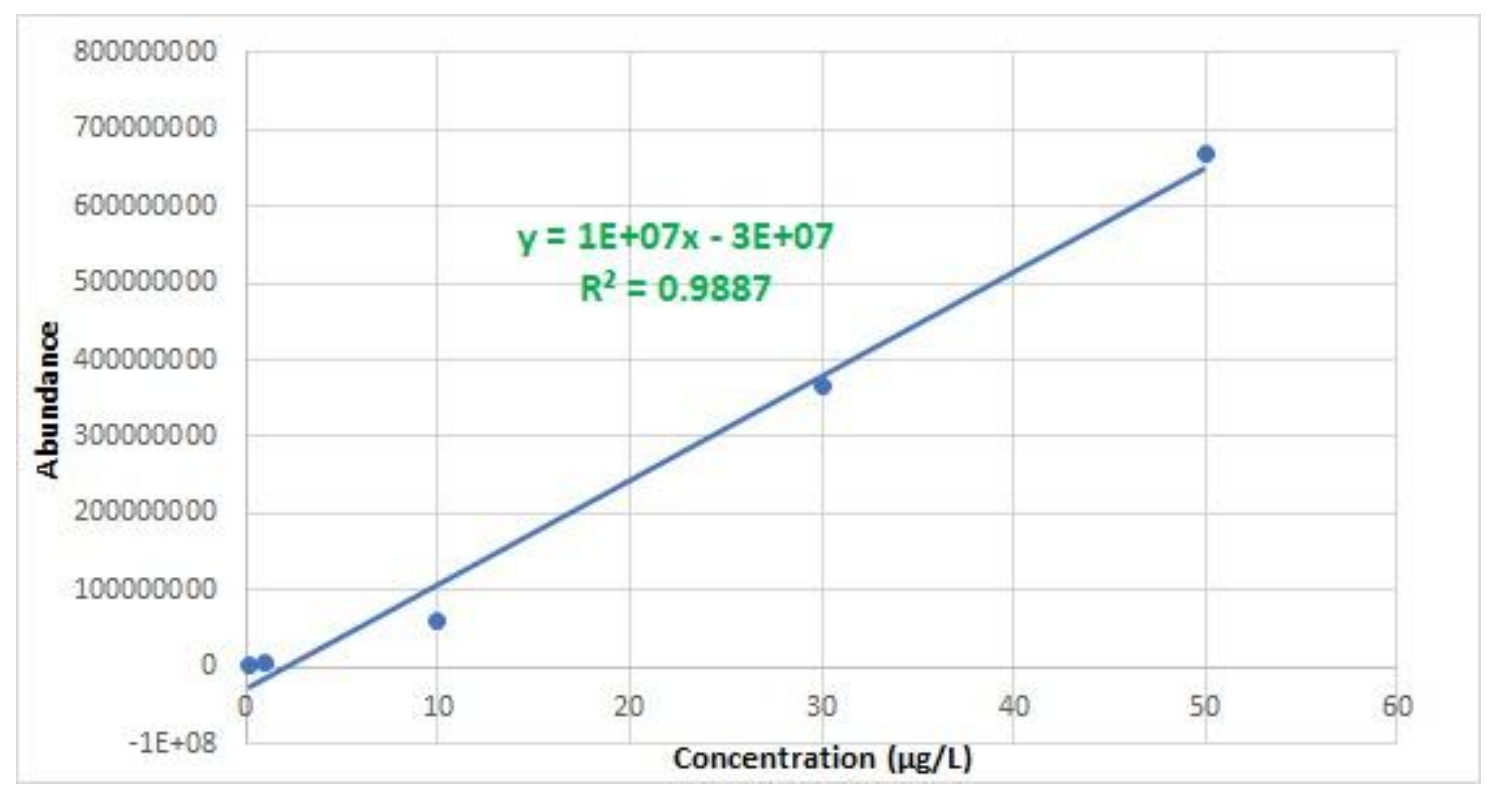

Figure 1. Standard curve of atrazine that was analyzed using GC-MS on HP 5MS separation column

Table 1. Accuracy and precision of atrazine herbicide expressed as percentages of recovery, coefficients of variation (CV), limits of detection (LOD), limit of quantification (LOQ), and linearity parameters

\begin{tabular}{lcc}
\hline \multirow{2}{*}{ aparameter } & \multicolumn{2}{c}{ Fortification Concentration $^{\mathbf{a}}(\boldsymbol{\mu g} / \mathbf{L})$} \\
\cline { 2 - 3 } & $\mathbf{5}$ & $\mathbf{1 0}$ \\
\hline Recovery $(\%) \pm \mathrm{RSD}$ & $94.7 \pm 4.09$ & $96.3 \pm 6.31$ \\
\hline $\mathrm{CV}(\%$, within assay) & 1.433 & 2.049 \\
$\mathrm{CV}(\%$, between assay) & 4.912 & 5.406 \\
\hline \multirow{2}{*}{ Method limits $(\mu \mathrm{g} / \mathrm{L})$} & $\mathrm{LOD}$ & 2.343112 \\
& $\mathrm{LOQ}$ & 7.100339 \\
\hline & $\mathrm{R}$ & 0.9886 \\
Linearity & Slope & 0.000006 \\
& $\mathrm{RSD}$ & 10000000 \\
\hline
\end{tabular}

${ }^{\mathrm{a}}$ Atrazine-fortified blank water samples were each assayed in five single determinations of the same concentration over one day (intra-assay) and over five consecutive days (inter-assay) determined using GC-MS.

In the current study, atrazine residues varied significantly in water samples collected from ElMahmoudia, Zarkone, Kom El-Nasr, Ficha, Kafr Tekla, Edfina, Zawiat Ghazal, Abou Hommos, Barket Ghatas, El-Kazaz, Kafr El-Dawwar, Abyss, Damanhur, Itay El Barud, Denchal, Kom Hamada, Monchat Nassar, Shubrakhit, Abu Menjouj, Elmasry village, Hosh Issa, El-Nubaria, Abu El Matamir (Mariout and Sidnawy), and Genaklis (Table 2). Results (arranged in the table from the least to the greatest detected value) showed that atrazine residues in surface irrigation water ranged from 3.125 \pm 0.0894 (at Kafer El-Dawwar) to $109.181 \pm 15.778 \mu \mathrm{g} / \mathrm{L}$ (at Hosh Essa). Such significant variation in atrazine levels in irrigation water between the 26 tested sites in El-Behera Governorate might highlight its application and frequency of use in these agricultural areas. 
Table 2. Atrazine concentration (mean \pm SD) in surface water samples collected from different sites in Elbehera Governorate, Egypt and measured using the GC-MS

\begin{tabular}{lrl} 
& \multicolumn{2}{c}{ Megion $\mathbf{\pm S D}$} \\
& $\boldsymbol{\mu g} / \mathbf{L}$ & \\
\hline Kafr El-Dawwar & 3.125 & 0.0894 \\
Damanhur & 3.157 & 0.1299 \\
Ficha & 3.268 & 0.1316 \\
Dunchal & 3.344 & 0.1370 \\
Abu El Matamir (Sidnawy) & 3.349 & 0.1382 \\
Zawiat Ghazal & 3.359 & 0.1380 \\
Barket |Ghatas & 3.470 & 0.1388 \\
Edfina & 3.554 & 0.1297 \\
El-Kazaz & 3.799 & 0.1344 \\
Monchat Nassar & 3.816 & 0.1405 \\
Zarkone & 3.823 & 0.1382 \\
El- Nubaria & 3.896 & 0.1395 \\
Abou Hommos & 3.903 & 0.2415 \\
Kom Hamada & 3.956 & 0.2088 \\
Kom El-Nasr & 4.093 & 0.1948 \\
Genaklis & 5.208 & 0.2182 \\
El- Mahmoudia & 5.821 & 0.3001 \\
Abu El Matamir (Mariout) & 6.411 & 0.3875 \\
Shubrakhit & 7.729 & 0.5894 \\
Kafr Tekla & 8.717 & 0.7214 \\
Abu Menjouj & 10.501 & 1.3305 \\
Abyss & 14.818 & 1.6487 \\
Elmasry village & 26.603 & 6.7841 \\
Itay El Barud & 43.614 & 8.6894 \\
Hosh Essa & 109.181 & 15.778 \\
\hline
\end{tabular}

Atrazine, an S-triazine herbicide, is highly mobile and persistent in water and the environment (Gamble et al., 1983; Hussein et al., 1996; Kramer et al., 2001). Therefore, its residues were detected in surface, ground, and drinking water samples (Gojmerac et al., 1996). In the current study, atrazine residues ranged from 3 to 109 $\mu \mathrm{g} / \mathrm{L}$. These comprehensive results might be due to applied quantity. Increased levels reported herein compared to what was found in previous research may be due to sampling collection after applying this herbicide, inspite of being banned in Egypt since 2005 under decision number 719, atrazine is still being used illegally as a major herbicide in corn and some other crops even in non-cultiveted lands. In literature, it was detected in surface water at concentrations exceeding $0.1 \mathrm{~g} / \mathrm{L}$ (Solomon et al., 1996; Environment Agency, 1997). Atrazine was the most commonly used in England during 1992 and 1993, and residue analysis studies revealed amount exceeded $0.2 \mu \mathrm{g} / \mathrm{L}$, the maximum permissible level (NRA 1995). Analysis of river surface water from northeastern Greece after solidphase extraction (SPE) extraction and injection in GCEI-MS, atrazine was one of the highly detected pesticides (Vryzas et al., 2009). Atrazine residues in Suquía River basin (Córdoba-Argentina) were 0.432 $\mu \mathrm{g} / \mathrm{L}$ after analysis using GC-MS (Bonansea et al., 2013). It was reported in groundwater in Spain at 0.5 $\mu \mathrm{g} / \mathrm{L}$ using the LC-MS-MS (Köck-Schulmeyer et al., 2014). Accordingly, atrazine stability and mobility in water systems might pose a risk of pollution to aquatic ecosystems. Its residues might be accumulated in aquatic organisms and be transferred to humans through the food chain. Therefore, limitation and tracking the use of this herbicide would have beneficial effects.

\section{REFERENCES}

Abouzinea, H.F., M.A.M. Ahmed, A.T. Eldabaa and M.S.A. Abd El-Wahed. 2013. A comparative study on the productivity of two yellow maize cultivars grown under various weed control management. Middle-East J. Agric. Res. 2: 56-67.

Ackerman, F. 2007. The economics of atrazine. Int. J. Occu. Environ. Health, 13: 437-445.

Ali, R., S.K. Khalil, S.M. Raza and H. Khan. 2003. Effect of herbicides and row spacing on maize (Zea mays L.). Pak. J. Weed Sci. Res. 9: 171-178. 
Anastassiades M., S.J. Lehotay and F.J. Schenck. 2003. Fast and Easy Multiresidue Method Employing Acetonitrile Extraction/Partitioning and Dispersive Solid-Phase Extraction for the Determination of Pesticide Residues in Produce. J AOAC Int, 86: 412-431.

AOAC (Association of Official Analytical Chemists) .2007. Pesticide residues in foods by acetonitrile extraction and partitioning with magnesium sulfate pp 1-9. https://nucleus.iaea.org/sites/fcris/Shared\%20Documents/ SOP/AOAC_2007_01.pdf

Bethsass, J and A. Colangelo. 2006. European Union bans atrazine, while the United States negotiates continued use. Int. J. Occu. Environ. Health, 12: 260-267.

Bonansea, R.I., M.V. Amé and D.A. Wunderlin. 2013. Determination of Priority Pesticides in Water Samples Combining SPE and SPME Coupled to GC-MS. A Case Study: Suquía River Basin (Argentina), Chemosphere. 90: 1860-69. DOI: 10.1016/j.chemosphere.2012.10.007.

Cooper, R.L., T.E. Stoker, L. Tyrey, J.M. Goldman and W.K. McElroy. 2000. Atrazine disrupts the hypothalamic control of pituitary-ovarian function. Toxicol Sci 53: 297307.

El-Sobky, E. E.A and N.Z.A. El-Naggar. 2016. Effect of weed control treatments and planting density in maize (Zea mays L.). Egypt. J. Agron. 38: 55-77.

Environment Agency. 1997. Pesticides in the Aquatic Environment.Update of the Report of the National Rivers Authority, Water Quality Series No. 26. National Centre for Toxic and Persistent.

FAOSTAT. 2021. Pesticides use in Egypt. https://www.fao.org/faostat/en/\#data/RP (visited online in December 2021).

Gamble, D.S., S.U. Khan and Q.S. Tee. 1983. Atrazine hydrolysis: Part I. Proton catalysis at 25 8C. Pestic. Sci 14: 537-45.

Gojmerac, T., B. Kartal, N. Bilandžić, B. Roić and R. Rajković-Janje. 1996. Seasonal atrazine contamination of drinking water in pig-breeding farm surroundings in agricultural and industrial areas of Croatia. Bull. Environ. Contam. Toxicol. 56: 225-230.

Gojmerac, T., M. Koršić, J. Pleadin, M. Žurić and R. Rajković-Janje. 2004. Serum luteinizing hormone response to administration of gonadotrophin-releasing hormone to atrazine-treated gilts. Vet. Human Toxicol. 46: 245-247.

Hussein, S.Y., M.A. El-Nasser and S.M. Ahmed. 1996. Comparative studies on the effects of herbicide atrazine on freshwater fish Oreochromis niloticus and Chrysichthyes auratus at Assiut, Egypt. Bull. Environ. Contam. Toxicol. 57: 503-510.

ICH. 2005. International conference on the harmonization of technical requirements for the registration of pharmaceuticals for human use, ICH harmonized tripartite guideline, Validation of analytical procedures: text and methodology Q2(R1), Complementary guideline on methodology. https://database.ich.org/sites/default/files/Q2_R1__Guideli $\underline{\text { ne.pdf }}$
Khaliq, T., T. Mohmood and A. Masood. 2004. Effectiveness of farmyard manure, poultry manure and nitrogen for corn (Zea mays) productivity. Int .J. Agric. Biol. 2: 260-263.

Köck-Schulmeyer, M., A. Ginebreda, C. Postigo, T. Garrido, J. Fraile, M. López de Alda and D. Barceló. 2014. FourYear Advanced Monitoring Program of Polar Pesticides in Groundwater of Catalonia (NE-Spain), Sci. Total Environ. 470-471: $\quad$ 1087-98.

DOI: 10.1016/j.scitotenv.2013.10.079.

Luciane, S., C. Attilio, A.R.S. Geslaine and D.C.G.S. Rita. 2010. New aspects on atrazine biodegradation. Braz. Arch. Biol. Technol. 53: 487-496.

Maceljski, M., G. Hrlec, Z. Ostojić, B. Cvjetković and K. Barić. 2005. Plant protection products in Croatia. Plant Prot. Bull. 2-3: 65-211.

Mahmoodi, S and R. Ali. 2009. Estimation of critical period for weed control in corn in Iran. Proceedings of World Academy of Sci., Engine. And Tech. 3: 67-72.

Moore, A and C. Waring. 1998. Mechanistic effects of a triazine pesticide on reproductive endocrine function in mature male Atlantic salmon (Salmo salar L.) parr. Pest Biochem Physiol. 62: 41-50

Myers, M.D. 2006. National field manual for the collection of water-quality data. Collection of water samples, US Geological survey techniques of water-resources investigations, Chapter A4. (Version 2.0, 9/2006). US Geological Survey TWRI Book

NRA. 1995. Pesticides in the Aquatic Environment, Report of the National Rivers Authority, Water Quality Series No. 26, HMSO p. 88.

Pannacci, E and A. Onofri. 2016. Alternatives to terbuthylazine for chemical weed control in maize. Communications in Biometry and Crop Science.11: 51-63.

Pathak, R.K and A.K. Dikshit. 2011. Atrazine and human health. Int. J. Ecosyst. 1: 14-23.

Radwan, F.I and M.A.A. Nassar. 2011. Response of Maize Hybrid to Biofertilization, Soil Nitrogen Application and Weed Control. Alex. Sci . Exch. J. 32: 409- 421.

SAS (Statistical Analysis System) . 2016. SAS Version 9.3. Procedure Guide. SAS Inc., Cary.

Solomon, K.R., D.B. Baker, R.P. Richards, K.R. Dixon, S.J. Klaine , T.W. La Point, R.J. Kendall, C.P. Weisskopf, J.M. Giddings, J.P. Giesy, L.W. Hall and W.M. Williams. 1996. Ecological risk assessment of atrazine in North American surface waters. Environ. Toxicol. Chem. 15: 3176.

Topp, E., H. Zhu, S.M. Nour, S. Houot, M. Lewis and D. Cuppels. 2000. Characterization of an atrazine-degrading Pseudaminobacter sp. isolated from Canadian and French agricultural soils. Appl. Environ. Microbiol. 66: 27732782 . 
US Environmental Protection Agency (USEPA). 1988 Method 525. Determination of organic compounds in drinking water by liquid-solid extraction and capillary column gas chromatography/mass spectrometry. In: Methods for the determination of organic compounds in drinking water. Cincinnati, $\mathrm{OH}$, Environmental Monitoring Systems Laboratory, 1988: 325-356 (EPA Report No. EPA-600/4-88/039; US NTIS PB89-220461).

Vryzas, Z., G. Vassiliou, C. Alexoudis and E. PapadopoulouMourkidou. 2009. Spatial and Temporal Distribution of Pesticide Residues in Surface Waters in Northeastern
Greece. Water Research. 43: 1-10. http://dx.doi.org/10.1016/j.watres.2008.09.021

Waring, C.P and A. Moore. 2004. The effect of atrazine on Atlantic salmon (Salmo salar) smolts in fresh water and after seawater transfer. Aquat. Toxicol. 66: 94-104.

WHO. 1996. Guidelines for drinking-water quality, $2^{\text {nd }}$ ed. Vol.2. Health criteria and other supporting information. World Health Organization, Geneva, 1996.

Williamson, S., A. Ball and J. Pretty. 2008. Trends in pesticide use and drivers for safer pest management in four African countries. Crop Prot. 27:1327-34.

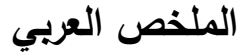

\section{متبقيات مبيد الأترازين في المياه السطحية من مناطق زراعية مختلفة بمحافظة البحيرة ، مصر}

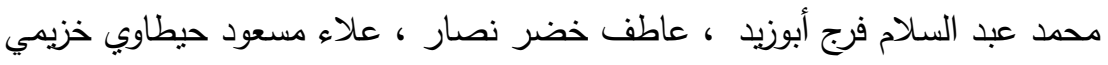

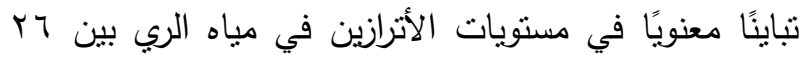

موقعًا نم اختبارها. عينات المياه من كفر الدوار احتوت على لئى

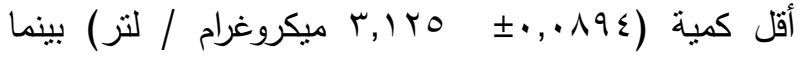

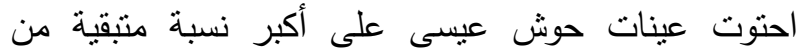

الأترازين (10,VVA

تمثل النتائج المتحصل عليها اتجاهات وكميات الأترازين

المستخدمة في محافظة البحيرة. قد تكون هذه النتائج مقلقة

بالنسبة للآثار الضارة المحتملة بسبب الاستخدام غير الأمثل

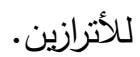

الكلمات المفتاحية: أترازين، مبيدات الحشائش، المياه

السطحية ، النظام البيئي المائي، GC-MS ، متبقيات .
تساهم مبيدات الحشائش بشكل كبير في زيادة وتعزيز كل

من انتاج الدحاصيل وجودتها من خلال مكافحة|الحشائش التي تنافس هذه المحاصيل. ومع ذللك ، فإن الإفراط في استخدام هذه المواد الكيميائية قد يؤثر سلبًا على الكائنات

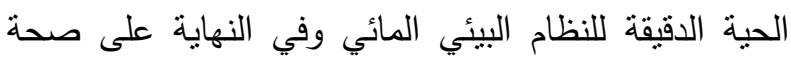
الإنسان. لذلك ، هدفت الدراسة الحالية إلى قياس بقايا مبيد الحشائش أنرازين المطبق بكثافة في عينات المياه السطحية للري من محافظة البحيرة ، و التى تعتبر المحافظة الزراعية

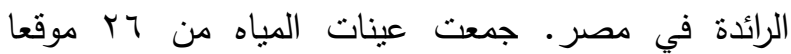
بمحافظة البحيرة وتم تحليلها باستخدام كروماتوجرافيا الغاز مقرونة بكاشف مطياف الكتلة (GC-MS). أظهرت النتائج 